\title{
PRODUÇÃO DO ESPAÇO GEOGRÁFICO: PROBLEMAS AMBIENTAIS E SEGREGAÇÃO SOCIOESPACIAL EM RONDONÓPOLIS (MT)
}

\author{
Kelbiane Alves Rodrigues \\ Geografia pela Universidade Federal de Mato Grosso (UFMT), Campus Universitário de Rondonópolis \\ Kelbiane geo@outlook.com
}

Caio Augusto Marques dos Santos

Professor do curso de Geografia da Universidade Federal de Rondonópolis (UFR) kiomarques@hotmail.com

Júlio César Zandonadi

Instituto Federal de São Paulo (IFSP), Campus de Cubatão Julio zandonadi@hotmail.com

Érika Cristina Nesta Silva

Professora do curso de Geografia da Universidade Federal de Rondonópolis(UFR) erikanesta@yahoo.com.br

\section{RESUMO}

Os problemas ambientais acontecem na esteira da produção do espaço. De tal modo, se o espaço produzido é diferencial e desigual entre (e para) as classes e frações de classes sociais, supõe-se que assim também são os problemas ambientais decorrentes. Desdobrase, portanto, da ideia aventada o objetivo do presente trabalho, ou seja, discutir a relação entre problemas ambientais urbanos e a segregação socioespacial em três bairros de Rondonópolis (MT): Jardim Carlos Bezerra I e II e Parque Residencial Buriti. Para tal, em trabalhos de campo, a partir de registro fotográfico, foram identificados problemas ambientais nessas áreas. As seguintes questões nortearam a reflexão: a) agentes distintos de produção do espaço urbano decorrem em quantidade/qualidade de problemas ambientais? b) loteamentos em que há predomínio de populações com menores rendimentos possuem maior volume de problemas ambientais e esses são mais graves? c) as causas dos problemas ambientais estão relacionadas ao segmento social que ocupa os espaços ou às fragilidades do meio natural frente ao uso e ocupação da terra? Por meio dos resultados alcançados, percebeu-se que os problemas ambientais são somados às condições sociais e econômicas constitutivas da segregação socioespacial derivada da produção capitalista do espaço.
\end{abstract}

Palavras-chave: Desigualdade espacial. Desigualdade ambiental. Relação sociedadenatureza.

\section{GEOGRAPHICAL SPACE PRODUCTION: ENVIRONMENTAL PROBLEMS AND SOCIO SPATIAL SEGREGATION IN RONDONOPOLIS-MT}

\begin{abstract}
Environmental problems arise in the wake of the production of space. Thus, if the space produced is differential and unequal between (and for) the classes and fractions of social classes, the hypothesis arises that so will the resulting environmental problems. As a result, the idea unfolds, and the objective of the present work: to discuss the relationship between urban environmental problems and the socio-spatial segregation of three neighborhoods in Rondonópolis-MT: Jardim Carlos Bezerra I and II and the Buriti Residential Park. To this end, in the field work, using photographic records, the environmental problems in the areas were identified. The following questions guided the reflection: a) Do different agents of urban space production result in quantity / quality of environmental problems? b) Do subdivisions with a predominance of populations with lower incomes have a greater quantity and worse environmental problems? c) Are the causes of environmental problems related to the socia segment it occupies or to the fragilities of the natural environment in relation to the use and occupation of land? Through the results achieved, it was noticed that environmental problems are added to the social and economic conditions that constitute the socio-spatial segregation resulting from the capitalist production of space.
\end{abstract}

Keywords: Spatial inequality. Environmental inequality. Society-nature relationship.

$\begin{array}{lllll}\text { Caminhos de Geografia } \quad \text { Uberlândia-MG } & \text { v. 22, n. 83 } & \text { out./2021 } & \text { p. 118-132 } & \text { Página } 118\end{array}$




\section{INTRODUÇÃO}

Diante da intensificação do processo de urbanização e expansão das cidades no Brasil, sobretudo a partir da década de 1970, os problemas ambientais eclodiram em quantidade e qualidade.

Não se discute a necessidade e o fato de o homem, organizado em sociedade, assentar-se sobre uma base física - superfície da crosta terrestre composta por rochas, solos e sedimentos inconsolidados, que se encontram esculturados nas mais diversas formas de relevo. Esse substrato físico possui uma organização e estruturação que resulta de um conjunto de processos e dinâmicas ligados à natureza, com metabolismos intercambiáveis de energia e matéria entre os diferentes elementos naturais (rocha, solo, relevo, água, clima, vegetação etc.).

Quando esses elementos naturais são apropriados, ocupados e utilizados pelas sociedades em suas relações sociais de (re)produção, tornam-se recursos sujeitos à incorporação/transformação no mundo da/em mercadoria. Além disso, os processos e dinâmicas de formação e/ou alteração da natureza, ora ajustados aos processos e dinâmicas da sociedade, ora em descompasso, resultam em problemas, ao mesmo tempo, de cunho espacial e ambiental.

Vale destacar a relativização que deve ser estabelecida quando se menciona o termo problema. Os problemas são produzidos e se manifestam, em quantidade e qualidade, diferentemente pelas (e entre) classes e frações de classes sociais, bem como nos espaços ocupados e produzidos por elas.

Com base no que foi exposto, o presente trabalho objetiva levantar e discutir questões para o debate acerca da relação de problemas ambientais urbanos e a segregação socioespacial sob três aspectos: a) agentes distintos de produção do espaço urbano decorrem em quantidade/qualidade de problemas ambientais? b) loteamentos em que há predomínio de populações com menores rendimentos possuem maior volume de problemas ambientais e esses são mais graves? c) as causas dos problemas ambientais estão relacionadas ao segmento social que ocupa os espaços ou às fragilidades do meio natural frente ao uso e ocupação da terra?

Cabe ressaltar que não foram buscadas neste trabalho respostas finalistas e causais, tampouco um protagonista na relação que se pretende entender. Procurou-se compreendê-la tendo em vista as seguintes perspectivas gerais: não há problema ambiental sem produção do espaço e, na medida em que o espaço é produzido, por vezes com (e por) segregação socioespacial, os problemas ambientais podem ser gerados e/ou intensificados.

Para tanto, escolheu-se como área de estudo a cidade de Rondonópolis, em Mato Grosso (figura 1) e três dos seus bairros: Jardim Carlos Gomes Bezerra I e II e Parque Residencial Buriti (figura 2).

A título de contextualização e apresentação geral, vale citar que Rondonópolis é um município de porte médio localizado no sul do estado, distante cerca de 210 quilômetros da capital Cuiabá. De acordo com o último censo demográfico do Instituto Brasileiro de Geografia e Estatística (IBGE, 2010), possuía 195.476 habitantes. Em 2020, a população estimada é de 236.042 habitantes. Seu território possui 4.686,622 quilômetros quadrados (IBGE, 2010), parte dele localizado no bioma Cerrado e outra parte no Pantanal. O PIB per capita em 2017 era de $\mathrm{R} \$ 43.175,1^{1}$ (ao longo do trabalho, será evidenciado como a média obscurece a realidade).

No que se refere aos bairros escolhidos, três aspectos se destacam para o interesse deste estudo: a) o fato de terem sido produzidos por agentes distintos (o Parque Residencial Buriti pela iniciativa privada, uma imobiliária, e os bairros Jardim Carlos Gomes Bezerra I e II pelo poder público, a prefeitura municipal); b) suas localizações no espaço urbano: os três estão localizados na zona norte da cidade, contudo, o Buriti em situação contígua à malha urbana e distante cerca de dois quilômetros do centro urbano principal; os outros dois bairros estão situados na periferia da cidade e distantes aproximadamente cinco quilômetros do centro urbano principal; c) a renda média per capita no primeiro bairro ultrapassa $R \$ 1.200,00$, ao passo que, nos outros dois, fica próxima de $R \$ 450,00$ (IBGE, 2010).

Assim, os autores do trabalho têm claro que utilizar apenas três bairros de uma cidade de porte médio do Mato Grosso configura um universo de análise bastante restrito e pouco respalda uma tentativa de generalização e conclusão. Todavia, pensa-se, a partir deles e das questões levantadas, ser possível postular um debate, acreditando-se que as situações preconizadas estão presentes em boa parte das cidades brasileiras.

${ }^{1}$ Disponível em: <https://www.ibge.gov.br/cidades-e-estados/mt/rondonopolis.html> Acesso em: 15 dez. 2020.

$\begin{array}{lllll}\text { Caminhos de Geografia } & \text { Uberlândia-MG } & \text { v. 22, n. } 83 & \text { out./2021 } & \text { p. 118-132 }\end{array}$


Kelbiane Alves Rodrigues

Produção do espaço geográfico: problemas ambientais e segregação socioespacial em Rondonópolis (MT)

Figura 1 - Localização do perímetro urbano de Rondonópolis (MT).

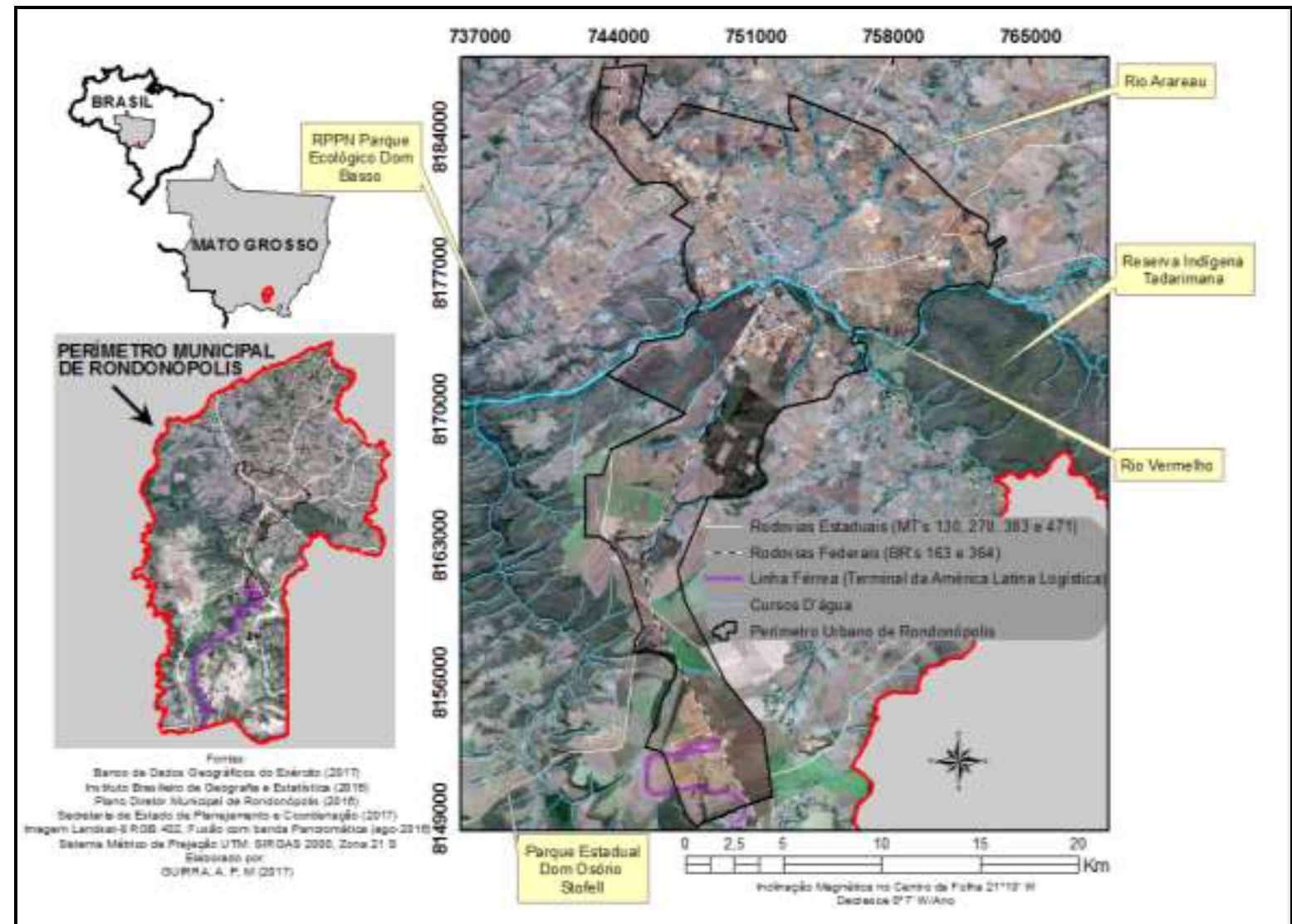

Fonte - GUIRRA (2017).

Figura 2 - Localização dos bairros Jardim Carlos Gomes Bezerra I e II e Parque Residencial Buriti.

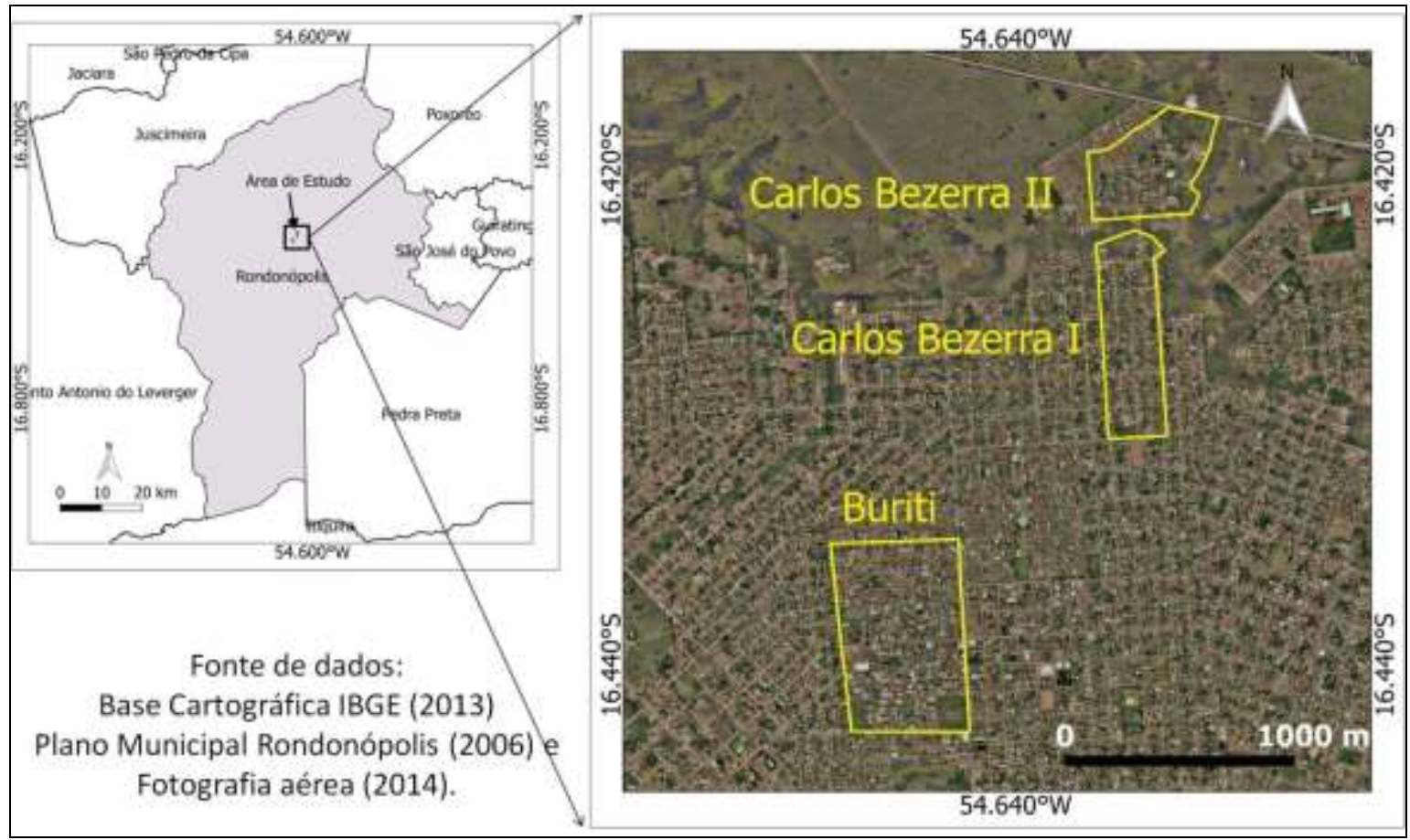

Fonte - RODRIGUES (2017).

$\begin{array}{lllll}\text { Caminhos de Geografia } & \text { Uberlândia-MG } & \text { v. 22, n. } 83 & \text { out./2021 } & \text { p. 118-132 }\end{array}$




\section{PROCEDIMENTOS METODOLÓGICOS}

Do ponto de vista teórico, a perspectiva que se adotou para levantar os dados e posteriormente analisá-los foi a de totalidade. Partiu-se da noção de que os problemas ambientais ocorrem na esteira da produção do espaço. Os dois aspectos são indissociáveis. Os problemas ambientais condicionam a produção do espaço, bem como é nesse processo que são produzidos e significados pelas sociedades. Assim, na medida em que o espaço é diferencial e desigual, entende-se que isso também ocorre com os problemas ambientais.

No aspecto prático, os procedimentos adotados seguiram dois caminhos metodológicos. O primeiro se refere à escolha dos bairros estudados e o segundo está relacionado às formas de levantamento dos dados acerca dos problemas ambientais.

A seleção de áreas da cidade teve como ponto de partida a renda média da população de três bairros, que necessitaria ser discrepante. Depois, apresentar situações locacionais em relação ao centro urbano principal também destoantes. Ambos os critérios tiveram o intuito de analisar e comparar os problemas ambientais levando em consideração a dinâmica de segregação socioespacial. Um segundo aspecto avaliado foi a topografia, procurando-se manter semelhanças nesse quesito, com o objetivo de ter uma variável ambiental constante para comparação dos problemas ambientais.

Optou-se pela topografia tendo-se em vista que, a partir dela, estão relacionados e condicionados processos de escoamento superficial acelerado, erosão, movimentos de massa, alagamentos, inundação etc. Dessa forma, comparar a ocorrência de problemas ambientais em bairros de topografias contrastantes poderia influenciar no aumento e na intensidade dos problemas ambientais. Além disso, os tipos de solo, por acompanharem mudanças topográficas, são os mesmos nos bairros. Tal fator é importante considerando-se os diferentes comportamentos diante dos processos anteriormente citados.

Tentou-se manter constante ainda a área do bairro e o número de habitantes para relativizar a relação causal: maior número de pessoas implica maiores problemas ambientais. No entanto, isso não foi possível diante da heterogeneidade do espaço urbano de Rondonópolis.

O levantamento dos problemas ambientais dos bairros foi efetuado empiricamente em trabalhos de campo e os problemas foram registrados com imagens fotográficas. Destaca-se que não foram realizados os registros quantitativo (lote a lote ou quadra a quadra) e qualitativo dos problemas identificados, por não haver parâmetros rígidos de comparação diante de problemas e magnitudes que poderiam ser diferentes. Igualmente, não foram efetuadas medidas absolutas, como no caso de contaminação de solos e águas. Por exemplo, um dos bairros poderia apresentar vários sulcos erosivos, porém o outro poderia ter uma voçoroca de alguns metros de profundidade.

A forma de apresentar e discutir os problemas ambientais registrados nos bairros foi dificultada, sobremaneira, tendo em vista a necessidade de estabelecer comparações entre realidades distintas. Em decorrência da premissa de que as condições materiais das populações interferem em como são produzidos os problemas e como são vividos, as comparações se tornam ainda mais difíceis diante dos procedimentos adotados.

Assim, questionando-se se a gravidade ou intensidade dos problemas ambientais se igualaria à sua quantidade, pela dificuldade de se estabelecer comparações em virtude da heterogeneidade dos bairros e dos motivos anteriormente elencados, decidiu-se por mostrar os problemas registrados em cada bairro e discutir como podem afetar a população em virtude das diferentes condições materiais.

No tópico teórico-conceitual a seguir, procurou-se elucidar as dificuldades encontradas.

\section{PROBLEMAS AMBIENTAIS URBANOS E A SEGREGAÇÃO SOCIOESPACIAL}

Definir problema ambiental é uma tarefa árdua. Embora haja vários exemplos, nem todos possuem parâmetros físicos e químicos que servem de referência na sua determinação. Os índices de qualidade das águas e dos solos são exemplos de problemas ambientais com limites de referência

$\begin{array}{lllll}\text { Caminhos de Geografia } \quad \text { Uberlândia-MG } & \text { v. 22, n. 83 } & \text { out./2021 } & \text { p. 118-132 } & \text { Página } 121\end{array}$


determinados por órgãos de pesquisa. Neles são apontados os valores quantitativos de concentração de elementos químicos ou padrões físicos que, quando ultrapassados, indicam contaminação do ambiente. No entanto, mesmo tendo parâmetros criteriosamente estabelecidos e baseados em quantidade, raramente, é avaliado como e quem sofre os problemas (qualidade), além de, em determinadas situações, haver dificuldades de se apontar o causador de tais problemas. Ou seja, num cenário hipotético, classes e frações de classes sociais submetidas à mesma contaminação de um manancial - que pode não ter seu agente causador facilmente identificado - por suas condições materiais objetivas, lidarão com o problema e o sofrerão de formas distintas (alguns têm possibilidade de comprar água engarrafada, enquanto outros não). A urgência de busca por contenções e, mais ainda, de soluções dos problemas para uns pode ser de motivação puramente estética, para outros pode significar a própria sobrevivência.

Por outro lado, problemas como erosão, assoreamento, movimentos de massa e inundação, por exemplo, não possuem parâmetros ou tamanhos de referência que os caracterizam como problemas. Nesses casos, os parâmetros e as referências são apenas de nível classificatório do processo, como na distinção entre tipos de movimentos de massa pela morfologia da cicatriz produzida, ou profundidades referentes às classificações de feições erosivas, como as ravinas e voçorocas (em medidas absolutas, como centímetros e metros ou considerando o alcance do aquífero freático, com o aumento progressivo da profundidade da feição). Geralmente, há indicadores no terreno que tornam possível estabelecer um nível crítico em que determinado fenômeno pode atingir vidas humanas (causando problemas). Contudo, da mesma forma que a situação hipostasiada anteriormente, determinado segmento social sofrerá (mais ou menos) a depender de sua condição material objetiva (em geral, a renda).Considera-se que natureza e sociedade são ontologicamente diferentes, que possuem processos e dinâmicas com ritmos e intensidades próprios, contudo, na sua relação metabólica, por vezes, esses processos e dinâmicas se cruzam, o que altera seus ritmos e intensidades, quantidades e qualidades.

Para exemplificar, são usadas as inundações, entendidas como um fenômeno natural em que há elevação do nível regular das águas em épocas de altos índices pluviométricos. Antes das apropriações e ocupações humanas das áreas de várzeas, esses episódios possuíam determinado ritmo e frequência, que passaram a ser alterados com o avanço das impermeabilizações dadas pelas pavimentações e edificações. $O$ indicativo no terreno são as áreas relativamente planas das várzeas, que vão sendo tomadas pelas águas.

Vale ressaltar uma busca de superar a ideia de problema ambiental como algo distante das pessoas. Procura-se, ao contrário da ordem estabelecida, naturalizar a sociedade (aspecto bio-orgânico da espécie humana) e socializar o ambiente (afastar a ideia de ambiente = natureza externa ao homem), isto é, ao mencionar que seus processos e dinâmicas ora se ajustam ora se descompassam dos fenômenos naturais, ressalta-se que dessas interações resultam problemas que podem afetar vidas (prejuízos sociais e mortes). É por isso que se torna árduo assumir uma definição de problema ambiental, justamente por atingir e afetar desigualmente diferentes classes e frações de classes sociais com ritmos e intensidades igualmente distintas. Assume-se, portanto, que voçorocas de dimensões semelhantes em dois bairros diferentes provocarão transtornos diferentes. Igualmente acontece com os eventos de movimentos de massa em áreas de morro, que atingem sobretudo camadas mais pobres da população, as quais buscam locais mais baratos para morar, com preços estabelecidos dentro da lógica capitalista de produção e distribuição do espaço, em que o mercado imobiliário influencia diretamente nos valores das parcelas da terra urbana e, com isso, ajuda na segregação socioespacial.

No âmbito do debate entre a relação sociedade e natureza, seus processos e dinâmicas, é importante enfatizar que se está diante de um momento ímpar no que se refere à urbanização, em que tal se expande de modo intenso, incorporando novos territórios e alterando paisagens, modos de vida e relações de produção.

Autores como Lefebvre (2008), De Matteis (1998) e Reis (2007), este para o caso brasileiro, de modo geral, delimitam as mudanças no âmbito da produção nas décadas de 1960 e 1970, as quais caracterizam as alterações no espaço urbano nas décadas de 1970 e 1980, em que o processo

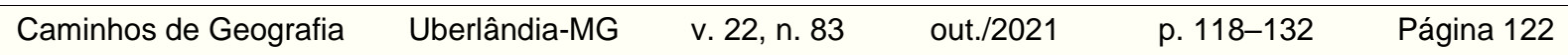


implode com a acentuação da centralidade da cidade e do espaço urbano e explode com a expansão da cidade e do urbano, tanto no que diz respeito à multiplicação do número de cidades, como à sua expansão. No conjunto dessas mudanças, se vê a acentuação de dinâmicas urbanas, entre elas a de segregação socioespacial, que parece ocorrer, de modo concomitante, à geração de problemas ambientais.

Trata-se de uma dinâmica que vem à luz nas cidades com o advento da produção fordista, tanto pela acentuação da divisão das classes em segmentos de níveis de consumo desiguais como pelo advento da cidade planejada, que compartimenta o espaço urbano de acordo com os níveis de renda e consumo das populações.

Castells (1983, p. 201) define tal dinâmica como a "tendência à organização do espaço em zonas de forte homogeneidade social interna e com intensa disparidade compreendida não só em termos de diferença, como também de hierarquia". Correa (1989) avança na definição ao tratar a segregação como diferenciação residencial, que consiste na existência e reprodução dos diferentes grupos sociais, definindo, desse modo, a divisão social do trabalho, sendo explicitamente a separação espacial das diferentes classes sociais fragmentadas.

Entre as causas da segregação, Castells (1983) afirma que a distribuição dos locais de residência segue as leis gerais de distribuição dos produtos em função da capacidade social dos indivíduos, o que, no âmbito do modo de produção capitalista, se dá em função de renda, status profissional, nível de instrução, filiação étnica, fase do ciclo da vida etc., mas sendo, sobretudo, um resultado da distribuição desigual da renda.

Para Correa (1989), a distribuição residencial desigual está diretamente associada ao meio de reprodução social, agindo como um elemento condicionador da sociedade, pois, diferentes áreas residenciais fornecem distintos meios de interação social, bem como diferentes graus de acessibilidade a recursos e a equipamentos urbanos.

Assim, pode-se distinguir diversos tipos de segregação.

Primeiramente, a segregação involuntária ou induzida ou imposta, que se identifica quando populações de baixo poder aquisitivo são realocadas de um espaço para outro, no interior da cidade, em conformidade com a dinâmica de especulação imobiliária e de ações do poder público (SOUZA, 2003). É possível exemplificar a partir de projetos de desfavelamento, em que as populações são removidas para outros espaços de moradia, vários desses mais distantes dos locais de trabalho e estudo, dificultando a mobilidade das pessoas. Ou mesmo, por sua faixa de renda, as populações não têm outras opções de moradia senão as áreas em que os preços do solo urbano são condizentes com suas possibilidades de aquisição.

Outro tipo é a segregação voluntária, espontânea ou autossegregação, efetuada pelas populações com elevado poder aquisitivo que fazem a opção de se afastar, se apartar ou se isolar da/na cidade (SOUZA, 2003; CARLOS, 2004). Carlos (2004) chama atenção que esse tipo de segregação se refere a uma estratégia de classe, em que uma parcela da população, a partir da diferenciação de renda, se localiza distintamente na cidade, uma vez que a localização está subordinada à propriedade privada.

Contudo, para o debate proposto neste artigo, é essencial refletir sobre as consequências da segregação socioespacial. Sobarzo Miño (2000) aponta três consequências: espaciais, de convivência social e de distribuição do poder, as quais são inerentes à segregação e ocorrem isoladamente ou de modo articulado.

Corrêa (1989) afirma que, entre as consequências espaciais que a segregação implica, estão as dinâmicas das terras no âmbito da cidade, uma vez que os terrenos com maiores preços são utilizados para as melhores residências e pelos grupos de maiores rendimentos, enquanto os terrenos com preços mais baixos e de pior localização são utilizados para construções de residências com qualidade inferior e/ou precárias pelos grupos de menores rendimentos. Carlos (1992) destaca a questão da relocalização dos grupos de maior renda para as áreas periféricas, fugindo de barulho, congestionamento e poluição, características das áreas centrais dos núcleos metropolitanos. Ainda

$\begin{array}{lllll}\text { Caminhos de Geografia } \quad \text { Uberlândia-MG } & \text { v. 22, n. } 83 & \text { out./2021 } & \text { p. 118-132 } & \text { Página } 123\end{array}$


que a tendência não se restrinja a elas, em cidades de menor porte se observa tal relocalização em busca de maiores terrenos ou mesmo isolamento socioespacial. Essa tendência de abandono da área central pelos grupos de maiores rendimentos pode gerar consequências, tal como a degradação da área central, deixando de ser um espaço atrativo, tendo em vista que os grupos com maiores rendimentos também são aqueles com maiores possibilidades tanto de investimento quanto de poder político.

Em relação à convivência social dos habitantes da cidade, a segregação socioespacial apresenta diversas repercussões. Sposito (1996) ressalta a diminuição ou mesmo rompimento da comunicação entre as pessoas, da circulação entre os subespaços e do diálogo entre os diferentes, o que pode caracterizar a fragmentação do espaço da cidade. Souza (2003) avança no sentido de que menos segregação possibilitaria maiores chances de interação entre grupos sociais diferentes e maior interação contribuiria para a demolição de preconceitos, pois a convivência favorece a tolerância e a segregação realimenta a intolerância.

De certo modo, associado às repercussões espaciais, no que se refere à promoção de infraestruturas, serviços e equipamentos urbanos, Sobarzo Miño (2000) menciona que a separação residencial das classes sociais no âmbito da cidade promove a concentração espacial do poder político e econômico, pois as áreas que reúnem os grupos com maiores rendimentos têm maior poder político, uma vez que possuem capacidade de influenciar as decisões e políticas públicas em seu favor; o que representa diretamente o aumento do preço da terra de uns em detrimento do preço da terra de outros, acentuando-se cada vez mais a segregação socioespacial no âmbito da cidade.

Diante de tal contexto, em relação a Rondonópolis, a segregação socioespacial é condição para a desigual manutenção de ritmos das dinâmicas da natureza, vinculados tanto à capacidade econômica para esta manutenção e preservação ambiental como à capacidade econômica de implantação de tipos de edificações que promovam maior ou menor intervenção nos ritmos das dinâmicas naturais. Além disso, se tem o poder político de influenciar políticas públicas que visem a conservação ambiental, como coleta de esgoto e resíduos sólidos.

A seguir, são apresentadas, descritas e discutidas as características dos bairros no que se refere ao tema central do trabalho: a relação dos problemas ambientais observados durante as pesquisas de campo e a segregação socioespacial.

\section{Parque Residencial Buriti}

Os processos de apropriação e ocupação do Parque Residencial Buriti começaram a ser viabilizados no ano de 1999, momento em que a N.C. Empreendimentos Imobiliários Ltda. adquiriu uma área de 428.470,00 metros quadrados, sendo 160.865,03 metros quadrados destinados a uso institucional e $267.604,97$ metros quadrados de área parcelada. Atualmente, o bairro possui 37 quadras, com terrenos que variam de 403 a 594 metros quadrados.

O serviço de coleta de resíduos sólidos ocorre quatro vezes por semana, sendo um deles destinado à coleta seletiva. Embora serviços urbanos como coleta de lixo, rede de esgoto e manutenção asfáltica do bairro sejam de responsabilidade da prefeitura municipal, a N.C. Empreendimentos Imobiliários Ltda. presta os serviços de coleta de entulhos e galhos de árvores, limpeza de terrenos não construídos e de limpeza das ruas.

No quadro 1, é possível observar o número de habitantes e a renda média per capita da população do bairro. Na figura 3, ilustra-se o padrão construtivo das moradias. Nota-se pelas imagens que as residências são de alvenaria, com tamanho e acabamento condizentes com o poder aquisitivo das pessoas que residem no bairro, além da existência de muros, portões e cercas elétricas, o que se relaciona com a tentativa de proteção, inclusive de bens materiais adquiríveis nessa faixa de renda. Ainda em relação aos materiais construtivos, cabe observar a presença, em algumas residências, de telhas de cerâmica com pintura clara, material esse que auxilia em termos de maior conforto térmico no interior das residências, proporcionando um ambiente mais fresco em comparação a outros tipos de cobertura.

Caminhos de Geografia Uberlândia-MG $\quad$ v. 22, n. $83 \quad$ out./2021 p. 118-132 Página 124


Quadro 1 - Número de habitantes e renda média per capita da população no bairro Parque Residencial Buriti

\begin{tabular}{|c|c|c|}
\hline Bairro & Habitantes & Renda média \\
\hline Parque Residencial Buriti & 732 & $\mathrm{R} \$ 1.241,99$ \\
\hline \multicolumn{2}{|c|}{ Fonte - IBGE (2010). ${ }^{*} \mathrm{R} \$ 510,00$ era o salário-mínimo em 2010. }
\end{tabular}

Figura 3 - Exemplos do padrão construtivo das moradias do bairro Parque Residencial Buriti.

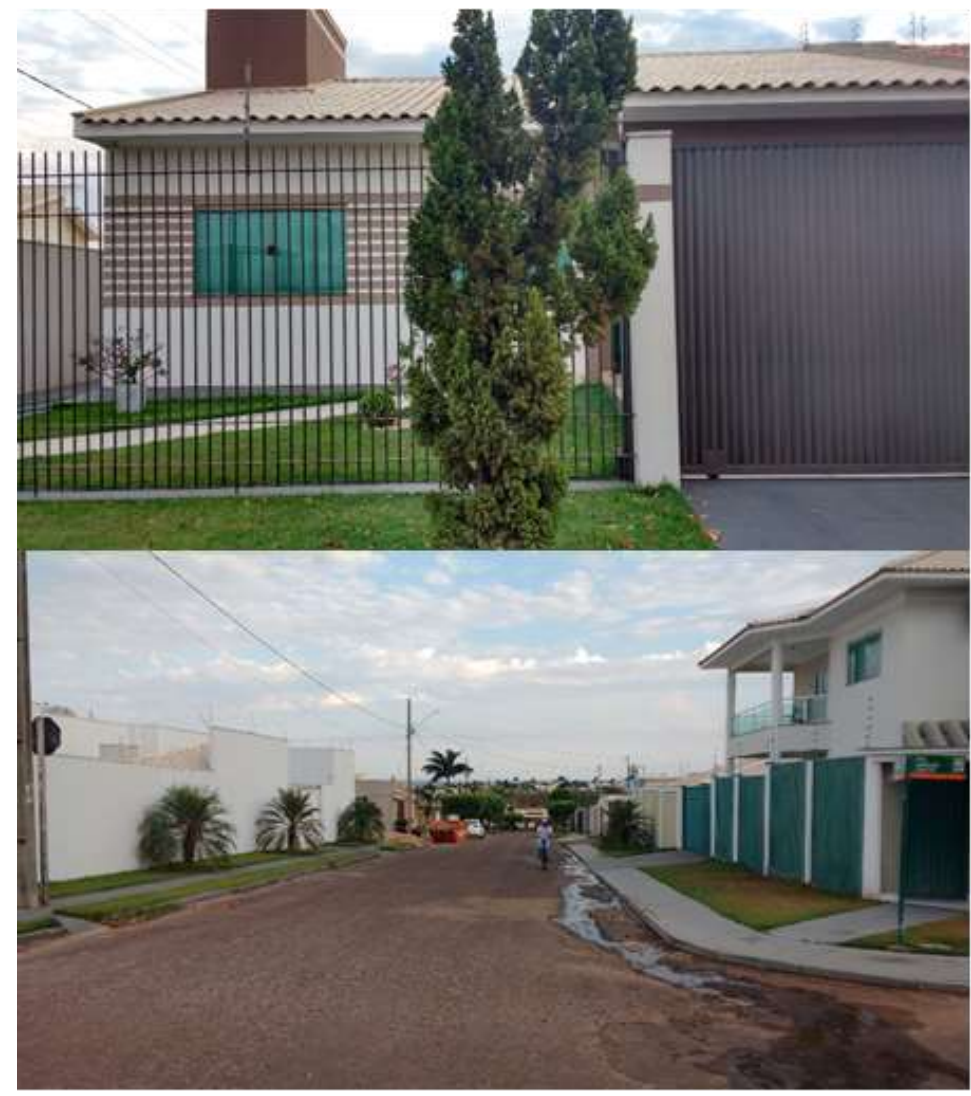

Fonte - RODRIGUES (2017).

Nos trabalhos de campo, foram observados os seguintes problemas ambientais: sulcos erosivos em várias ruas não asfaltas, águas servidas a céu aberto, moradias insalubres (falta de conforto térmico, no caso de residências com pé direito baixo e com pouca circulação de ar em razão do excessivo fechamento com muros e portões altos), assim como resíduos sólidos depositados nas ruas e em terrenos baldios.

No Parque Residencial Buriti, foi notada com relativa frequência, sobretudo nos terrenos baldios, deposição de resíduos sólidos (restos de construção). Problema esse que pode incorrer, nos momentos de chuva, em arraste dos materiais e sedimentos (erosão) e deposição nas partes mais baixas do terreno (figura 4).

Não foram observados outros problemas, acredita-se, em virtude da infraestrutura urbana relativamente bem consolidada do bairro (figura 5), quando comparado com os bairros Jardim Carlos Bezerra I e II.

\section{Jardim Carlos Gomes Bezerra I e II}

O Jardim Carlos Gomes Bezerra I surgiu no ano de 2001. Foi adquirida pela prefeitura municipal uma área de 398.975,00 metros quadrados, que teve como finalidade realizar o assentamento urbano de famílias carentes (Artigo $2^{\circ}$ da Lei $n^{0} 3.323$ de 12/07/2000, Arquivo da Prefeitura Municipal de Rondonópolis/Departamento de Cadastro, 2001). Entretanto, o decreto de aprovação do loteamento ocorreu somente em fevereiro de 2003, momento em que passou a ser denominado Jardim Carlos Gomes Bezerra I e Jardim Carlos Gomes Bezerra II, com área de 216.975,00 metros quadrados, sendo dividido em 27 quadras e com tamanhos de lote variando de 238 a 330 metros quadrados.

$\begin{array}{lllll}\text { Caminhos de Geografia } \quad \text { Uberlândia-MG } & \text { v. 22, n. 83 } & \text { out./2021 } & \text { p. 118-132 } & \text { Página } 125\end{array}$


Kelbiane Alves Rodrigues

Produção do espaço geográfico: problemas ambientais e segregação socioespacial em Rondonópolis (MT)

Caio Augusto Marques dos Santos Júlio César Zandonadi Érika Cristina Nesta Silva

Figura 4 - Deposição de resíduos sólidos em terrenos baldios no Parque Residencial Buriti (foto superior) e deposição de materiais e sedimentos nas partes baixas do terreno (foto inferior).

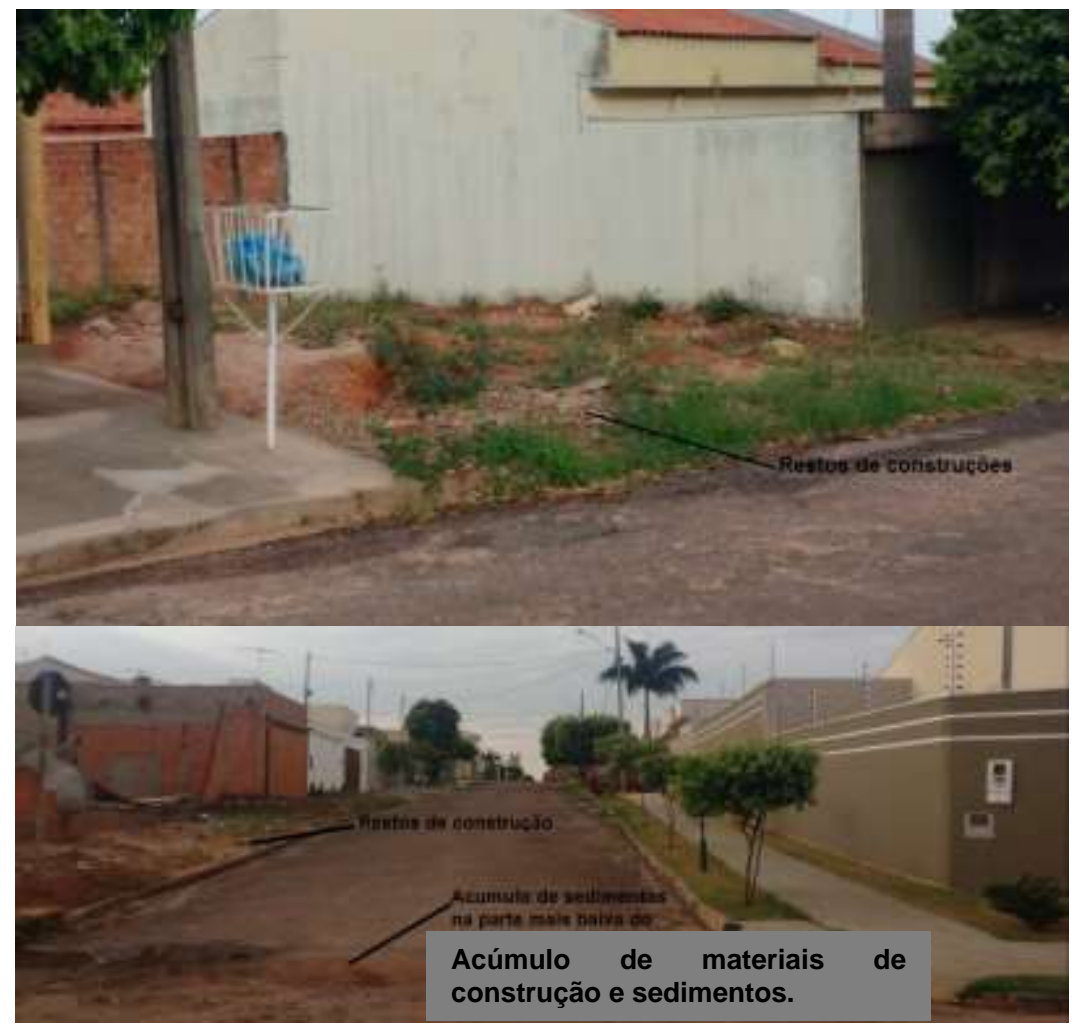

Fonte - RODRIGUES (2017).

Figura 5 - Infraestrutura urbana do Parque Residencial Buriti - praças (foto dos cantos superiores direito e esquerdo), caixa d'água para abastecimento público (foto do canto inferior esquerdo) e reserva municipal (foto do canto inferior direito, de uma das ruas de acesso).

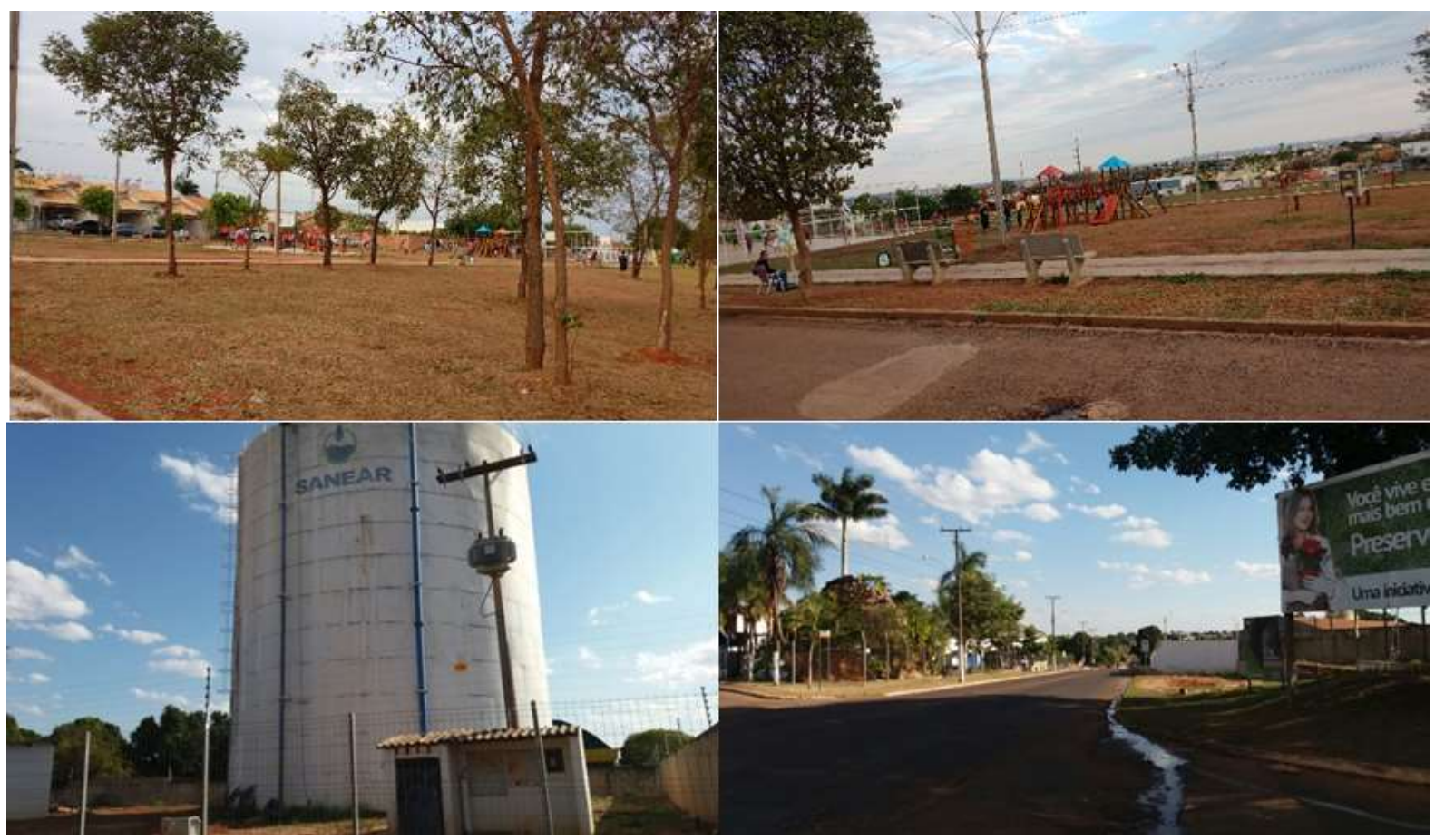

Fonte - RODRIGUES (2017). 
No quadro 2, são mostrados dados da população residente e renda média per capita e, na figura 6 , padrão construtivo das moradias. Na comparação das imagens referentes aos padrões construtivos do Jardim Carlos Gomes Bezerra I e II com os do Parque Residencial Buriti, são notáveis as diferenças em termos de tamanho, materiais construtivos e acabamentos das residências. Na figura 6 , pode-se observar que há construções sem acabamento, com coberturas que pouco garantem o conforto térmico (como telhas de fibrocimento) e ausência de portões (em alguns casos, há estruturas improvisadas para essa finalidade, como cercas e estruturas de madeira) e de cercamentos eletrificados. Trata-se de uma realidade de várias famílias com renda média baixa, cujas condições financeiras não permitem a compra de materiais de construção e acabamentos e contratação de mão de obra da construção civil, o que poderia auxiliar no aprimoramento de suas residências, ajudando também na melhora da qualidade de vida, inclusive no que se refere a conforto térmico e segurança.

Quadro 2 - Número de habitantes e renda média per capita da população dos bairros Jardim Carlos Gomes Bezerra I e II.

\begin{tabular}{|c|c|c|}
\hline Bairro & Habitantes & Renda média \\
\hline Jardim Carlos Gomes Bezerra I & 1.679 & $\mathrm{R} \$ 454,92$ \\
\hline Jardim Carlos Gomes Bezerra II & 615 & $\mathrm{R} \$ 402,06$ \\
\hline \multicolumn{2}{|c|}{ Fonte - IBGE (2010) ${ }^{*} \mathrm{R} \$ 510,00$ era o salário-mínimo em 2010.}
\end{tabular}

Fonte - IBGE (2010). * R\$ 510,00 era o salário-mínimo em 2010.

Figura 6 - Exemplos do padrão construtivo das moradias dos bairros Jardim Carlos Gomes Bezerra I e II.

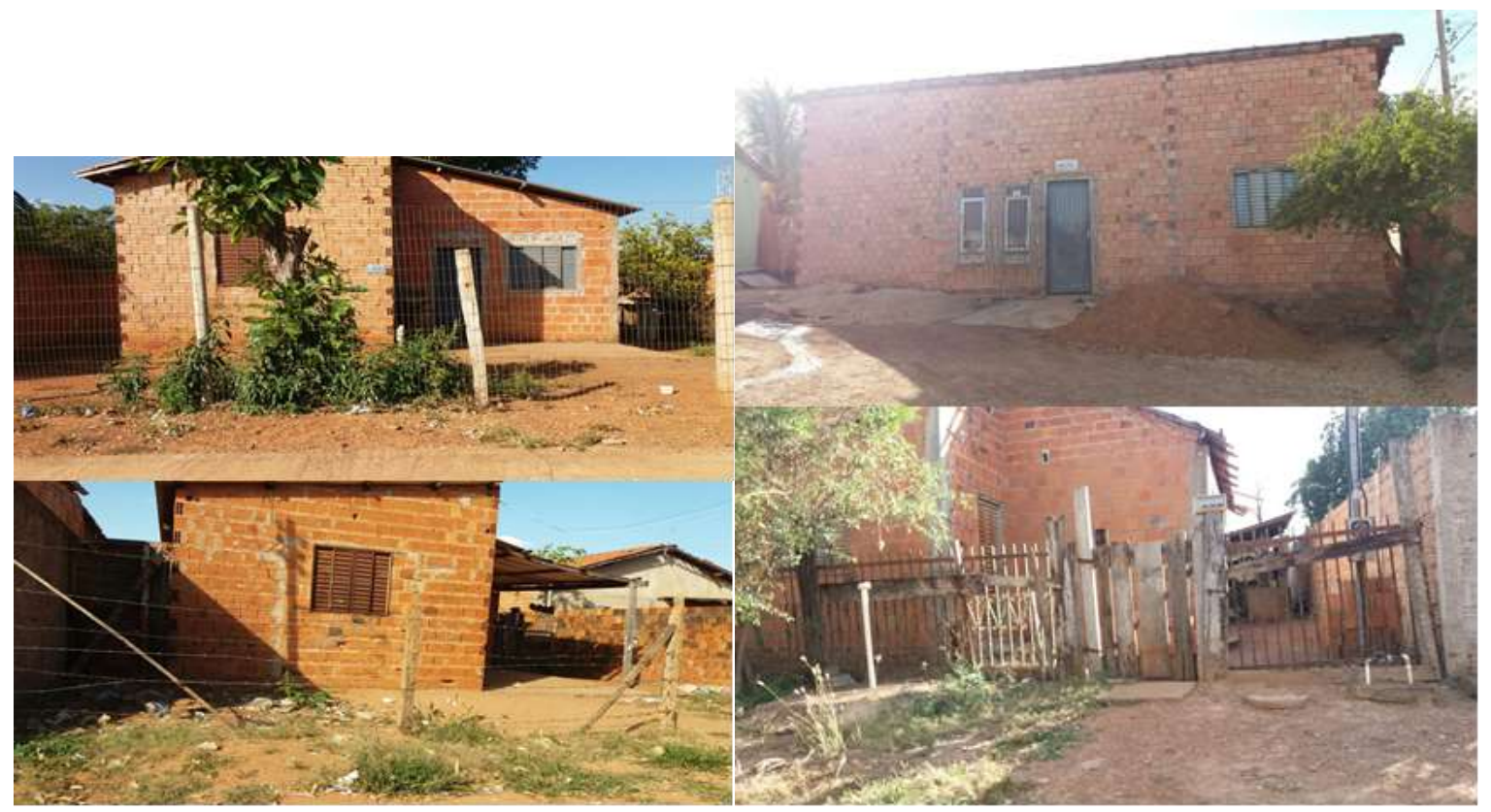

Fonte - RODRIGUES (2017).

Quanto aos problemas ambientais observados nesses bairros, os processos erosivos estão diretamente relacionados à ausência (ou deficiência) da infraestrutura urbana de asfaltamento (figura 7). Em decorrência do solo exposto e em ocasião das chuvas, formam-se sulcos erosivos que podem evoluir para ravinas e voçorocas, bem como interferem na mobilidade de veículos e pessoas. Além da falta de asfaltamento, nota-se a frequente inexistência ou inadequabilidade de calçadas, fato que prejudica especialmente a vida das pessoas com dificuldade de mobilidade.

A deposição de resíduos sólidos (e animais mortos) foi observada com bastante frequência nos bairros. A figura 8 ilustra o que foi visto nos trabalhos de campo.

$\begin{array}{lllll}\text { Caminhos de Geografia } \quad \text { Uberlândia-MG } & \text { v. 22, n. 83 } & \text { out./2021 } & \text { p. 118-132 } & \text { Página } 127\end{array}$


Produção do espaço geográfico: problemas ambientais e segregação socioespacial em Rondonópolis (MT)

Kelbiane Alves Rodrigues

Caio Augusto Marques dos Santos Júlio César Zandonadi Érika Cristina Nesta Silva

Figura 7 - Sulcos erosivos formados em ruas dos bairros Jardim Carlos Gomes Bezerra I e II.

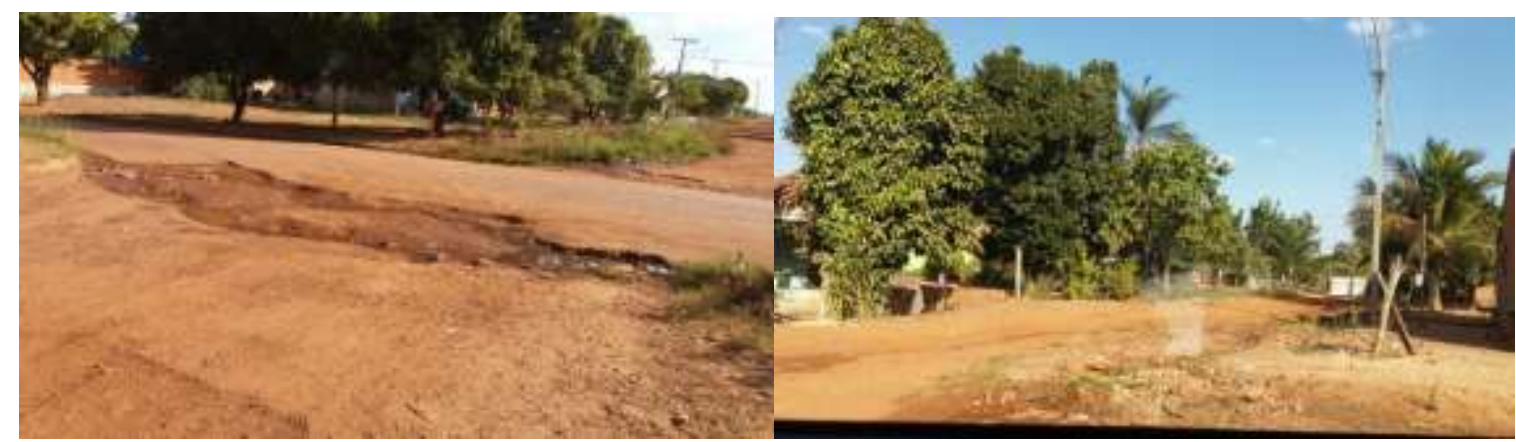

Fonte - RODRIGUES (2017).

Figura 8 - Deposição de resíduos sólidos em córregos canalizados nos bairros Jardim Carlos Gomes Bezerra I e II.
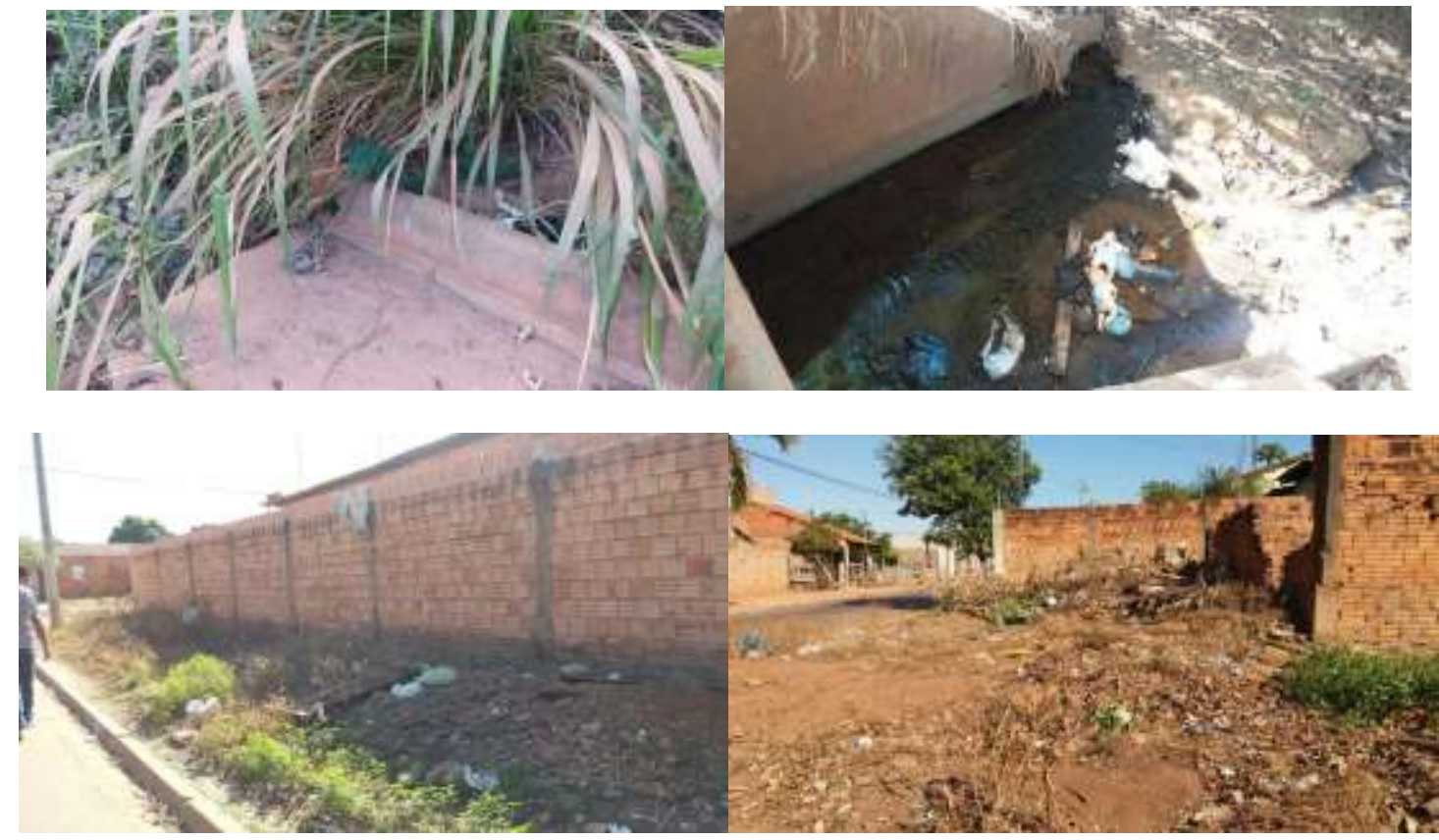

Fonte - RODRIGUES (2017).

A figura 9 ilustra um caso observado de interligação de alguns problemas ambientais. Em virtude da falta (ou pouca existência) de infraestrutura e serviços urbanos de coleta, a população deposita nas ruas resíduos sólidos (restos de materiais de construção) para tentar conter processos erosivos.

Figura 9 - Utilização de restos de construção para tentar conter processo erosivo nos bairros Jardim Carlos Gomes Bezerra I e II.

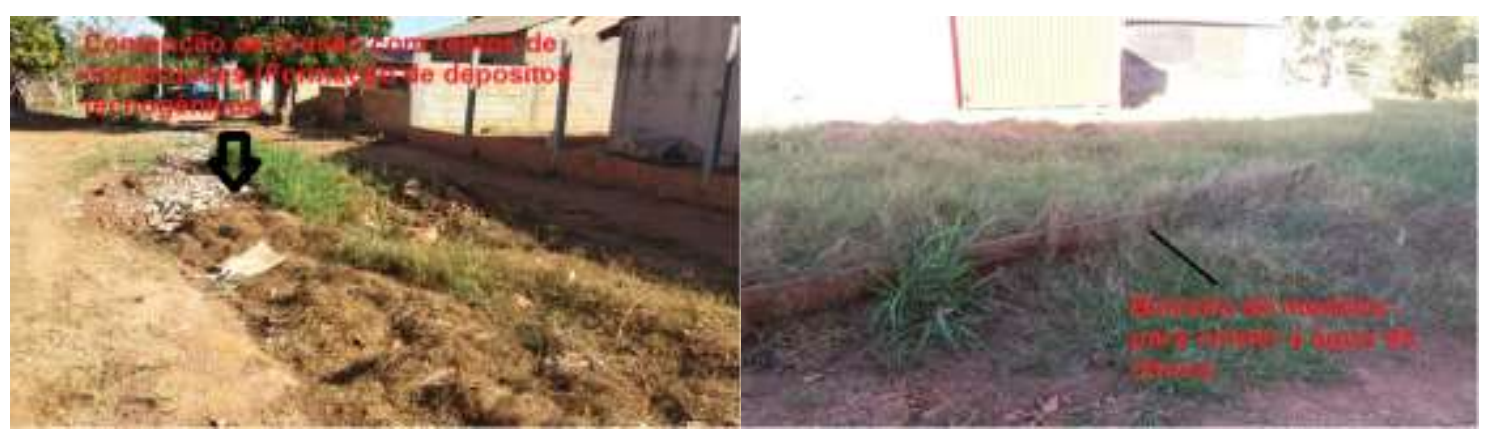

Fonte - RODRIGUES (2017).
Caminhos de Geografia
Uberlândia-MG
v. 22, n. 83
out./2021
p. $118-132$
Página 128 
As águas servidas também se configuram como um problema recorrente nos bairros por causa da deficiência da rede de drenagem pública, o que causa mau odor, além de favorecer a intensificação de processos erosivos em áreas não asfaltadas. Há casos de utilização dessas águas (com tubulações irregulares) para irrigação de pequenos cultivos de hortaliças (figura 10).

Figura 10 - Águas servidas escoando por rua do bairro Jardim Carlos Gomes Bezerra I (a foto da direita mostra a tubulação irregular coletando essas águas para irrigação).

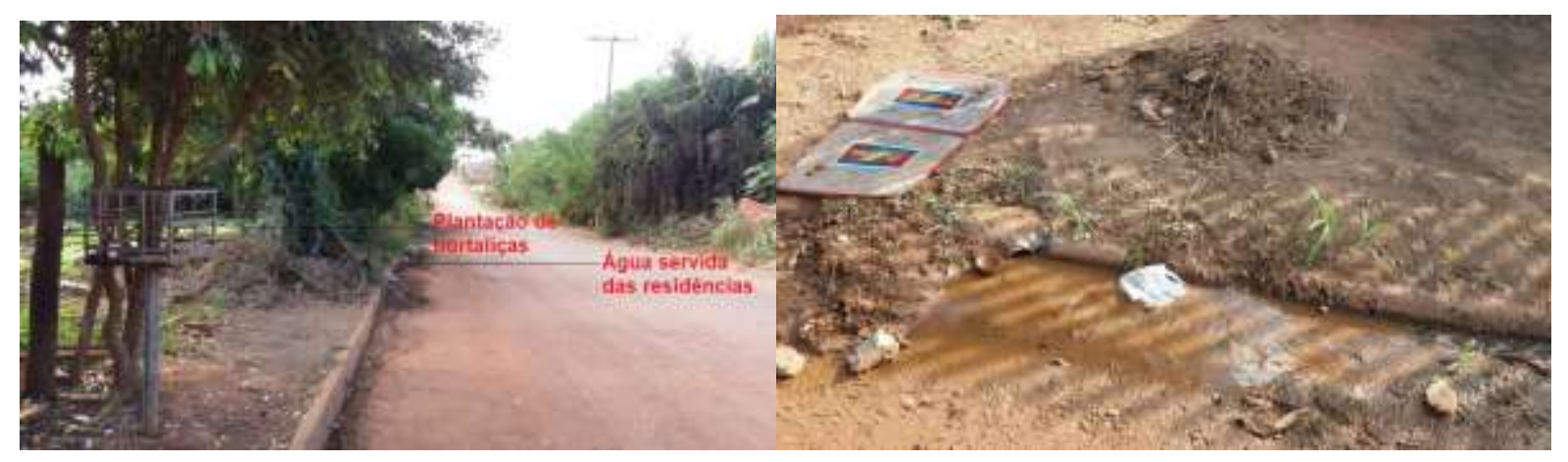

Fonte - RODRIGUES (2017).

É oportuno citar neste momento do trabalho duas passagens encontradas em Losurdo (2015). Elas aludem a um problema que há muito afeta os mais pobres. Na primeira passagem, o autor faz referência ao livro I de "O Capital", de Karl Marx.

A natureza presente nos bairros operários e nos bairros pobres dos centros urbanos oferece um espetáculo desolador: esses bairros foram edificados sem nenhuma consideração pela areação, só levando em conta o lucro que o construtor pode extrair, abandonados à absoluta sujeira e a uma imundície e um fedor espantosos (LOSURDO, 2015, p. 62).

$\mathrm{Na}$ segunda passagem, Losurdo (2015, p. 62) faz referência a Engels (sem mencionar uma obra específica).

Fornecendo uma das primeiríssimas análises da questão ecológica e ambiental, Engels ressalta como a lógica do lucro explica a poluição atmosférica (eis uma cidade 'coberta por uma nuvem cinzenta de fumaça de carvão') e dos rios (eis um 'córrego graveolente, escuro como breu' e eis 'uma água escura, que não se pode dizer se é riacho ou uma longa série de poças nauseabundas').

No quadro 3 , apresenta-se a comparação entre os bairros, tanto no que se refere à quantidade de população como a área dos lotes, renda média per capita das populações, agente de produção do espaço e problemas ambientais.

Tais dados permitem algumas considerações sobre a segregação socioespacial e os problemas ambientais na cidade de Rondonópolis, especificamente com relação aos bairros Jardim Carlos Gomes Bezerra I e II e Parque Residencial Buriti.

Em relação ao Parque Residencial Buriti, identifica-se que se trata de um empreendimento privado, associado à produção do espaço urbano por agentes de incorporação imobiliária privados. De modo geral, esses agentes produzem o espaço urbano de forma seletiva sendo destinado a determinados segmentos sociais, prioritariamente aos que podem pagar preços mais elevados da terra urbana, o que caracteriza dinâmicas de segregação voluntária, espontânea ou autossegregação de segmentos sociais que têm um leque mais amplo de escolhas espaciais no âmbito da cidade.

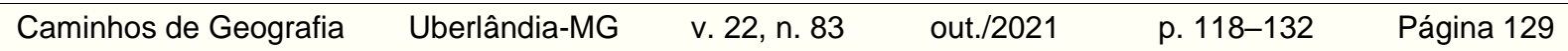


Quadro 3 - Comparação de renda média, tamanhos máximo e mínimo dos lotes, área total e número de habitantes dos bairros Jardim Carlos Gomes Bezerra I e II e Parque Residencial Buriti.

\begin{tabular}{|c|c|c|c|c|c|c|c|c|}
\hline Bairro & $\begin{array}{l}\text { Número } \\
\text { de } \\
\text { habitante } \\
\text { s }\end{array}$ & $\begin{array}{c}\text { Renda } \\
\text { média } \\
(\mathrm{R} \$)\end{array}$ & $\begin{array}{l}\text { Área } \\
\text { total } \\
\left(\mathrm{m}^{2}\right)\end{array}$ & $\begin{array}{c}\text { Área } \\
\text { por } \\
\text { habitant } \\
\text { e }\left(\mathrm{m}^{2}\right)\end{array}$ & $\begin{array}{c}\text { Tamanh } \\
0 \\
\text { máximo } \\
\text { dos } \\
\text { lotes } \\
\left(\mathrm{m}^{2}\right)\end{array}$ & $\begin{array}{c}\text { Tamanh } \\
0 \\
\text { mínimo } \\
\text { dos } \\
\text { lotes } \\
\left(\mathrm{m}^{2}\right)\end{array}$ & $\begin{array}{l}\text { Agente de } \\
\text { produção do } \\
\text { espaço }\end{array}$ & $\begin{array}{c}\text { Problema } \\
\text { s } \\
\text { ambientai } \\
\text { s }\end{array}$ \\
\hline $\begin{array}{c}\text { Jardim } \\
\text { Carlos } \\
\text { Gomes } \\
\text { Bezerra I }\end{array}$ & 1.679 & 454,92 & & 94,5 & & & & $\begin{array}{l}\text { - Sulcos } \\
\text { erosivos } \\
\text { - Águas } \\
\text { servidas a }\end{array}$ \\
\hline $\begin{array}{l}\text { Jardim } \\
\text { Carlos } \\
\text { Gomes } \\
\text { Bezerra II }\end{array}$ & 615 & 402,06 & $\begin{array}{c}216.97 \\
5\end{array}$ & & 330 & 238 & $\begin{array}{l}\text { Prefeitura } \\
\text { Municipal }\end{array}$ & $\begin{array}{c}\text { - Moradias } \\
\text { insalubres } \\
\text { - } \\
\text { Resíduos } \\
\text { sólidos em } \\
\text { ruas e } \\
\text { terrenos } \\
\text { baldios }\end{array}$ \\
\hline $\begin{array}{l}\text { Parque } \\
\text { Residenci } \\
\text { al Buriti }\end{array}$ & 732 & $\begin{array}{c}1.241,9 \\
9\end{array}$ & $\begin{array}{c}428.47 \\
0\end{array}$ & 585,3 & 594 & 403 & $\begin{array}{c}\text { N.C. } \\
\text { Empreendiment } \\
\text { os Imobiliários } \\
\text { Ltda. }\end{array}$ & $\begin{array}{c}\text { Problemas } \\
\text { relativos à } \\
\text { deposição } \\
\text { de } \\
\text { resíduos } \\
\text { sólidos em } \\
\text { terrenos } \\
\text { baldios }\end{array}$ \\
\hline
\end{tabular}

Fonte - Número de habitantes e renda média (IBGE, 2010); Área total do bairro e tamanhos dos lotes (Memorial Descritivo da Prefeitura Municipal de Rondonópolis).

Tal dinâmica pode estar associada a diversos fatores, mas destacam-se a dimensão dos lotes, com tamanho mínimo próximo de 400 metros quadrados e área por habitante de 585,3 metros quadrados, a situação do empreendimento em continuidade com a malha urbana constituída e a proximidade da área central. Fatores esses que podem induzir a elevação do preço da terra e, por conseguinte, a demanda e ocupação por segmentos com rendimentos médios elevados, o que, de certo modo, é identificado pelo padrão das edificações, realizadas a partir de projetos-padrão, com atuação de capitais do circuito formal da construção civil. Ainda em relação ao tamanho dos lotes, por serem maiores, permitem a existência de espaços com superfície permeável, como jardins e gramados, influenciando, assim, na redução de processos erosivos e outros problemas, como enxurradas e alagamentos.

Nos bairros Jardim Carlos Bezerra I e II, são observadas diferenças e desigualdades em relação à situação geográfica, sendo instalados nos limites e extremos da malha urbana constituída (Jardim Carlos Gomes Bezerra I) e em descontínuo à malha urbana constituída (Jardim Carlos Bezerra II). Entre as áreas da cidade mais distantes do espaço central, trata-se de um empreendimento implantado pelo Estado, destinado às populações com menores rendimentos, que, por sua condição de renda, estão determinadas a ocupar as piores áreas da cidade; neste caso, as mais afastadas do espaço central e com baixa presença de infraestrutura urbana adequada e serviços de manutenção em geral (coletas de determinados resíduos sólidos, limpeza etc.).

Pode-se tipificar tal condição como uma dinâmica de segregação induzida ou involuntária, pois dificilmente as populações que ocupam os lotes têm outras possibilidades de acesso formal à terra urbana no âmbito da cidade, restando-lhes as áreas limites da malha urbana constituída que, por isso, têm os menores preços. O padrão das construções demonstra essas condições, com a prática da autoconstrução, em que o próprio morador realiza a construção da moradia, com poucas

$\begin{array}{lllll}\text { Caminhos de Geografia } \quad \text { Uberlândia-MG } & \text { v. 22, n. 83 } & \text { out./2021 } & \text { p. 118-132 } & \text { Página } 130\end{array}$


benfeitorias e uso de materiais de construção diversos, não seguindo um padrão único, pois muitos são oriundos de "sobras" de outras obras, doações, compra de pequenos lotes etc. Ou seja, não se trata de uma obra que segue um plano "fechado" de produção da moradia, mas "aberto", sendo realizada a partir das possibilidades do proprietário, o que nas condições socioeconômicas dessas populações se dá num intervalo de tempo mais extenso se comparado com segmentos de maiores níveis de rendimentos.

Destarte, há nos bairros estudados uma estreita e íntima relação, impossível de ser dissociada, entre problemas ambientais e segregação socioespacial. Longe de buscar uma associação causal (quem causa ou o quê), procurou-se demonstrar que, além dos aspectos socioeconômicos e locacionais relacionados com a segregação socioespacial, os problemas ambientais se configuram como mais um elemento que a promove e agrava.

\section{CONSIDERAÇÕES FINAIS}

São resgatadas aqui as indagações introdutórias do trabalho para desenvolver as considerações que os resultados e as discussões feitas permitiram.

a) Agentes distintos de produção do espaço urbano decorrem em quantidade/qualidade de problemas ambientais? Sim. Pode-se observar que o fato de o Parque Residencial Buriti ter sido construído por uma imobiliária, que cuidou da produção espacial do bairro, tendo interesses lucrativos, faz com que os problemas ambientais sejam mínimos. Mesmo quando esses problemas ocorrem, por terem uma renda comparativamente maior que a dos moradores dos bairros Jardim Carlos Gomes Bezerra I e II, seus habitantes sofrem menos com eles, enquanto no Jardim Carlos Gomes Bezerra I e Il é empírico o predomínio da autoconstrução como modo de produção da moradia.

b) Loteamentos em que predominam populações com menores rendimentos possuem maior volume de problemas ambientais e esses são mais graves? Sim. Esse fato está diretamente vinculado ao agente de produção do espaço e aos seus interesses próprios. No caso dos bairros Jardim Carlos Gomes Bezerra I e II, a única finalidade da prefeitura ao criá-los foi assentar a população de baixa renda, buscando um local de reprodução da força de trabalho, não inserindo nos espaços ideais pertinentes à condição de vida das populações, seja em relação à qualidade das construções ou a problemas ambientais.

c) As causas dos problemas ambientais estão relacionadas ao segmento social que ocupa os espaços ou às fragilidades do meio natural frente ao uso e ocupação da terra? É simplório, reducionista, determinista e alienante associar as causas dos problemas ambientais à população, sobretudo de baixa renda, vinculando esse aspecto também à falta de instrução. É patente que este último fator pode ter alguma relevância, contudo, não levar em consideração as relações sociais de (re)produção material da vida estigmatiza sobremaneira as populações de renda mais baixa e reforça o caráter moralista/individual da meritocracia e da produção material da vida (darwinismo social). Significa afirmar que, se pudessem e tivessem condições (materiais e de conhecimento) de escolher, as populações de rendimentos mais baixos não produziriam (nem viveriam em) espaços degradados por problemas ambientais e, nem mesmo, aceitariam conviver com esses problemas, visto que teriam, também, maior poder político para reivindicar melhorias junto ao poder público. Há que se combater, dessa maneira, as causas (que são estruturais na ordem vigente dominante) que levam essas pessoas a não terem condições de escolher.

Por fim, ressalta-se o fator fragilidade do meio natural frente ao uso e à ocupação da terra. Aqui também deve-se ter cuidado com o determinismo: áreas mais frágeis a determinado uso e ocupação terão maiores e piores problemas. Tal fato depende do acesso ao aparato técnico adequado, que pode propiciar melhor adaptação, o qual, é claro, está vinculado às condições materiais objetivas produzidas e apropriadas de forma desigual no modo de produção capitalista.

\section{REFERÊNCIAS}

CENSO, I.B.G.E. v. 23, 2010. Disponível em: <http://www.censo2010.ibge.gov.br/> Acesso em: 22 mar. 2020.

CARLOS, A. F. A. A cidade. São Paulo: Contexto, 1992.

Caminhos de Geografia Uberlândia-MG $\quad$ v. 22, n. $83 \quad$ out./2021 p. 118-132 Página 131


O espaço urbano: novos escritos sobre a cidade. São Paulo: Contexto, 2004.

CASTELLS, M. A. A questão urbana. Rio de Janeiro: Paz e Terra, 1983.

CORREA, R. L. O espaço urbano. São Paulo: Ática, 1989.

DE MATTEIS, G. Suburbanización y periurbanización. Ciudades anglosajonas y ciudades latinas. In: MONCLÚS, F. J. (org.). La ciudad dispersa: suburbanización y nuevas periferias. Barcelona: CCCB, 1998.

LEFEBVRE, H. A Revolução Urbana. 3. reimpressão. Belo Horizonte: UFMG, 2008.

LOSURDO, Domenico. A luta de classes: uma história política e filosófica. Boitempo Editorial, 2015.

REIS, N. G. Sobre a dispersão em São Paulo. In: REIS, N. G.; TANAKA, M. S. (org.). Dispersão urbana: diálogo sobre pesquisas Brasil-Europa. São Paulo: FAU/USP, 2007.

RODRIGUES, K. A. Problemas ambientais urbanos em Rondonópolis - MT: os casos do loteamento parque Residencial Buriti e loteamento Jardim Carlos Gomes Bezerra I e parte II. 68 p. Rondonópolis, 2017. Monografia (Licenciatura em Geografia) - Universidade Federal de Mato Grosso, Campus Universitário de Rondonópolis.

SOBARZO MIÑO, O. A. A segregação socioespacial urbana. Formação, Presidente Prudente, n. 7, 2000.

SOUZA, M. L. ABC do desenvolvimento urbano. Rio de Janeiro: Bertrand Brasil, 2003.

SPOSITO, M. E. B. Reflexões sobre a natureza da segregação socioespacial nas cidades médias.

Revista de Geografia, Dourados, n. 4, p. 71-85, set.-dez. 1996.

Recebido em: 20/07/2020

Aceito para publicação em: 30/12/2020 